\title{
Syrian Refugees and Americans: Perceptions, Attitudes and Insights
}

\author{
Ismail Hakki Yigit \\ Mississippi State University, USA \\ Andrew Tatch \\ Mississippi State University, USA
}

\begin{abstract}
In recent years, the United States (US) has seen an influx of refugees from the Syrian Crisis, highlighted by a public declaration from then President Obama that 10,000 refugees would be admitted. National surveys suggested that roughly half of US citizens were uncomfortable with this decision. This study serves as an extension of these previous surveys by further elucidating the underlying causes of this discomfort. As such, this study explores Americans' perceptions of Syrian refugee resettlement as well as Syrians' perceptions of America using face to face interviews and content analysis. Analyses revealed conflicting meanings of immigration for both Syrians and Americans as well as co-occurring compassion and fear directed towards Syrian refugees. In addition, Syrian refugees perceived their American resettlement as an opportunity for engagement with society and to contribute socially and economically, while also noting their marginalization and stigmatization in their transitional countries. Americans expressed a lack of understanding of the legal status of Syrian refugees, often equating them with undocumented and illegal migrants. Americans held oppositional attitudes towards Syrian refugees, expressing both empathy towards and fear of terrorism. This study extends the literature on immigration through a more dynamic exploration of attitudes of both refugees and citizens in America, capitalizing on the distinct advantages of qualitative approaches.
\end{abstract}

KEYWORDS: Syrian refugees, qualitative study, perceptions of Americans, terrorism.

\section{Introduction}

The Syrian Civil War is an ongoing war affecting the lives of millions of people within the country, in neighboring countries, and overseas. The Syrian Civil War began during Arab Spring in early 2011, initiated by Syrian protests against President Bashar Al-Assad's government. Protest in different cities of the country turned into a rebellion of different military groups (Aydin \& Kaya, 2017; Icduygu, 2015; Jones, 2015). Most important, however, has been the rise of a brutal terrorist organization, the Islamic State (IS) - also known as the Islamic State of Iraq and al-Sham (ISIS) (Carasik, 2015; Gilsinan, 2015; Jones 2015) within territories of both Syria and Iraq. 


\section{Syrian Refugees and Americans}

After several years of bombing, the coalition forces provided military support and intelligence to local actors and government, resulting in the loss of most IS controlled territory by the end of 2017 (Adnan \& Coles, 2017). An important component of the war is the large concentration of foreign volunteer engagement; more than 20,000 foreign volunteers are involved in the war, and approximately 3,400 are from western countries (Jones, 2015). A primary concern regards the future of those foreign fighters after the war. Will they remain in Syria and Iraq or will they return to Western countries? This lack of clarity has led to concerns from people in Western countries, including the United States (US), in regards to refugee acceptance and the IS related fears. So far, more than 250,000 individuals have lost their lives and almost half of the country's population has been displaced, while around 4.2 million have left the country (Carasik, 2015; Gilsinan, 2015; Jones 2015).

Where have the displaced populations of Syria resettled? Recent studies indicate there are more than three million Syrian Refugees who resettled in Turkey and Lebanon (Faltis, 2014; Icduygu 2015; McNelly and Morland 2016; Aydin \& Kaya 2017). According to Rettberg and Gajjala (2015), media coverage, both mainstream and social, greatly increased in 2015 as more refugees arrived in European countries seeking political asylum.

Syrian refugees have been the subject of scholarly inquiry in recent years, including physical well-being and access to public health care systems in countries in which they settled (McNelly 2016; Dawson-Hahn et al. 2016; Sharara \& Kanj 2014), educational attainment and barriers in host countries (Akgul et al. 2015; Aydin \& Kaya 2017; Sirin \& Rogers-Sirin 2015;). Syrian refugee children have also been widely studied, with emphases on mental health (Sirin \& Rogers-Sirin 2015), adverse childhood experiences and well-being (Dejon et al. 2017), nutritional health of Syrian refugee children in the US (Dawson-Hahn et al. 2016), and risks of spread of infectious diseases among Syrian refugees (Sharara \& Kanj 2014).

According to the State Department's Worldwide Refugee Admissions Processing System (WRASP 2017) during the Fiscal Year (FY) of 2011 until the first two months of the FY 2018, 21,060 Syrian refugees had been admitted to the US. During the FY of 2016 alone, 12,587 Syrian refugees were accepted into the US. Like other immigrant groups, Syrian refugees arrive to the US with a variety of issues, including employment difficulties, housing, transportation, and medical needs (Aydin \& Kaya 2017; Kaya, 2015). While the US mainstream media covers Syrian refugees, we know little about perceptions of Syrian refugees towards the US; further, little is known about Americans' attitudes towards Syrian refugees.

Using 2013 data on American attitudes towards Syrian refugees and the Syrian crisis, Christophersen et al. (2013) found that 52\% of American felt that Syrian refugees were a threat to national stability. In addition, $82 \%$ of respondents believed that Syrian refugees were taking American jobs and causing wages to fall, while $90 \%$ felt that the Syrian conflict was negatively affecting the American economy. They also found that $50 \%$ of respondents believed that the Syrian refugees received unfair economic assistance. 


\section{Syrian Refugees and Americans}

Prior studies examining the Syrian refugee crisis have generally used data collected from refugee camps in neighboring countries of Syria (Aydin \& Kaya 2017; Akgul et al. 2015; Dejon et al. 2017). In addition, several studies have been conducted in the US pertaining to the admission of Syrian refugees, but these have utilized strictly quantitative approaches (Dawson-Hahn et al. 2016; Galston 2016; Hooper et al. 2017; Christophersen et al. 2013; Scarboro \& Yigit 2014). Based on a review of the literature, we note several gaps. We were unable to find any qualitative studies of Americans' perception of Syrian refugee resettlement in the US. Similarly, we were unable to locate any qualitative studies on Syrian refugee perceptions on the US. In hopes of filling this void, this study explores a range of attitudes and perceptions of US citizens towards Syrian refugees, as well as resettled Syrian refugees' perception of the US.

This study is important in several ways. First, it provides a detailed analysis of perceptions of Americans towards Syrian refugees using qualitative methods. Quantitative analyses on perceptions of Syrian resettlement showed that half of Americans are against the resettlements of Syrian refugees (Christophersen et al. 2013; Dawson-Hahn et al. 2016; Galston 2016). Despite these descriptive and useful findings, further inquiries on the reasons were not conducted. As an extension of the descriptive quantitative studies, we utilize a qualitative approach to examine the dynamics view of perceptions of Americans towards resettlement of Syrian refugees and Syrian perceptions of America.

\section{Theory and Literature}

To frame Syrian resettlement in the US, we rely on Massey et al. (1993) push and pull model of international migration. The push-pull model centers on negative (push) factors in the country of origin that drive migration from one country to another. In contrast, positive (pull) factors of the receiving country attract people to move to a new destination (Massey et al. 1993). Push and pull factors are typically economic, social, political, climate, or safety related. In sum, migrants generally move from countries with less advantages conditions (push factors) to destinations deemed to offer greater opportunities of security (pull factors) (Massey et al. 1993).

\section{Syrian Migration Patterns}

The first wave of Syrian immigrants arrived in the US between the late $19^{\text {th }}$ and early $20^{\text {th }}$ century (Cainkar 2009). These early immigrants were mostly Christian and were fleeing from violence in Syria (Zong 2015). The second wave of Syrian immigration was in response to the abolishment of the national-origin quota with the passing of Immigration and Nationality Act of 1965 (Aguirre \& Turner, 2010; Zong 2015; Cainkar 2009). This second wave resulted in substantial population increases, as Syrian immigrant admission tripled between 1960 and 2000 (from 17,000 to 55,000), further increased to over 60,000 after 2000 (Cainkar, 2009; Zong 2015). Most recently, a third wave of Syrian migrants were admitted after Syrian Civil War began in 2011. This resulted in a 43 percent increase in the number of migrants of Syrian origins between 2011 until 2014 (Zong 2015). 


\section{Syrian Refugees and Americans}

Figure 1 shows the Refugee Processing Center (RPC) summary of Syrian refugee admissions to the US between 2011 and 2018. The peak of admissions occurred in 2016, in which 12,587 Syrian refugees were accepted into the US.

Figure 1: Admission of Syrian Refugees to the US between Fiscal Year (FY) 2011 and 2018 by October 31, 2017.

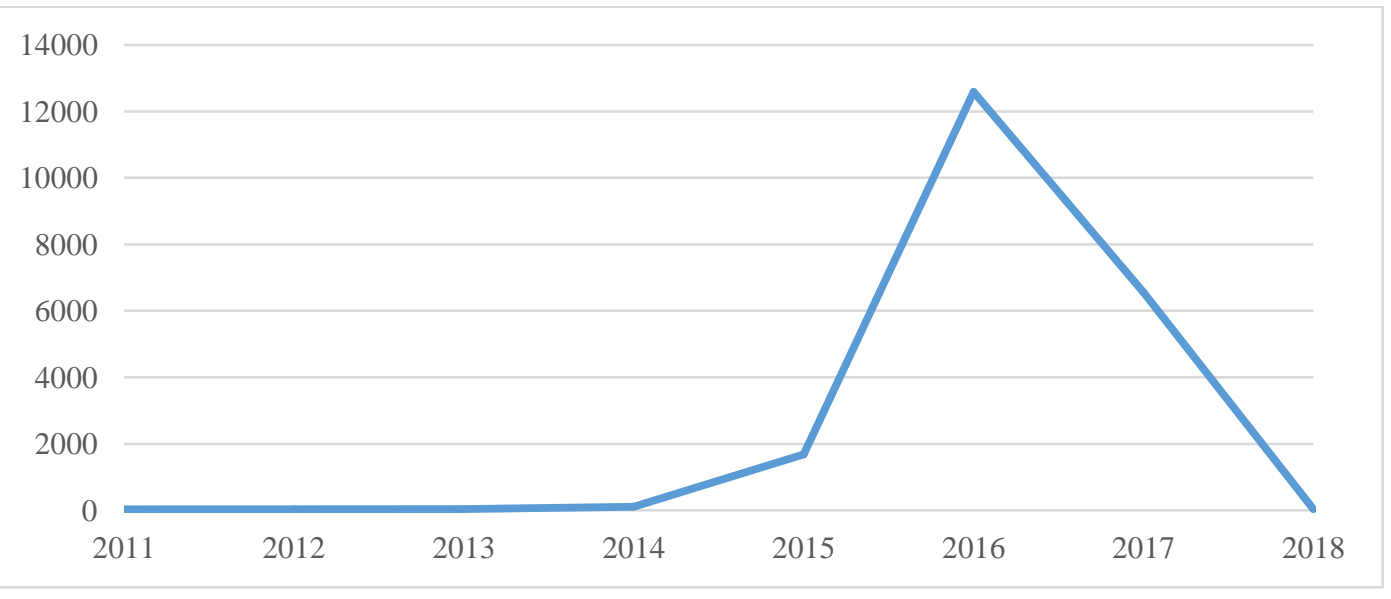

Based on data from the RPC, Syrian refugees comprised approximately $15 \%$ of the total refugees admitted in FY 2016, followed by $12.2 \%$ during the FY 2017. In contrast, only $2.7 \%$ of the admitted refugees were of Syrian origin during the first two months of FY 2018 (Figure 2).

Figure 2: Percent of Syrian Refugees of Total refugees to the US between FY 2011-2018.

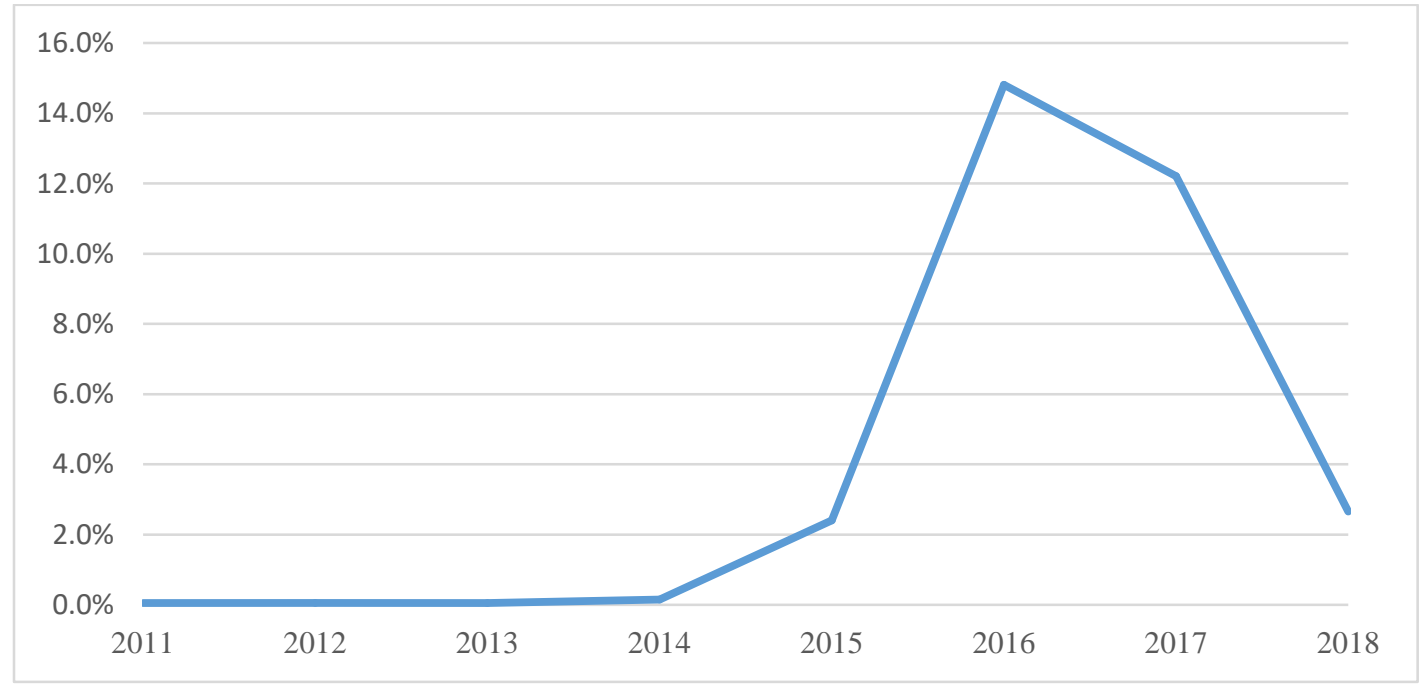

McNelly and Morland (2016) posited that Syrians accounted for 18 percent of the total refugee population admitted to the US in 2016, although RPC data showed that about 15 percent of the total refugees were from Syria in 2016. McNelly and Morland (2016) found that Syrian refugees arrived in the US with various issues, including the need to secure paid employment, transportation, housing accommodations, mental, and physical health issues.

By conducting focus group discussions, community mapping and photo elicitation, Dejong et al. (2017) explored adolescent Syrian refugees in the Beka'a valley of Lebanon and found that 


\section{Syrian Refugees and Americans}

both families and adolescents have been highly affected by the conflict in regards to educational opportunities and marital patterns. Specifically, adolescents reported lost educational opportunities and adolescent girls tended to marry young as a coping strategy to deal with survival risks.

Hooper et al. (2017) examined 941,000 refugee children from all refuge groups (age 10 years and younger) who lived with their parents in the US between 2009 and 2013. They found that many children in refugee families have strong family structures, high labor market participation, high education attainment, better access to health coverage and public benefits; in contrast, some risk factors, including low level of English proficiency and high poverty (Ersoy, 2015; Hooper et al. 2017). Children of refugee families indicate better outcomes compared to other types of immigrant groups because they benefit from US resettlement services (Hooper et al. 2017).

\section{Method and Data Sources}

\section{Research Design}

We employ both face to face interviews with Americans and content analyses of the online blog Humans of New York for Syrian refugees. Face to face interviews with American participants allow us to explore their perceptions of migration (Abbas \& Yigit 2015; Flick 2014; Weiss 1995). Through content analyses of Syrian refugees, we are able to explore perceptions of Syrian refugees about migration. Content analyses allow us to gain insight in regards to complex models of migration (Krippendorff 2003).

Qualitative methods provide in-depth information about human behavior (Flick 2014; Weiss 1995; Çitamak \& Yigit 2012). Through qualitative research we provide a better understanding of complex realities of given situations through open-ended questions and interaction with participants (Flick 2014). Prior studies have generally utilized quantitative methods to describe characteristics of the Syrian refugee population and predict causal relationships of their complex reality. Whereas qualitative methods allow us to describe and explain relationships, and the individual experiences of Syrian refugees. Quantitative approaches previously used to survey American attitudes were limited by their rigidity. As such, we employ face to face interviews to ask open-ended questions about their perceptions of Syrian refugees, in a way that allowed for greater depth and a deeper understanding of the processes that drive these attitudes.

\section{Participants}

Face to face interviews were conducted with Americans by the authors. Syrian perceptions were collected using secondary data from the online blog Humans of New York. For the face to face interview portion of the study, the target population was American individuals who live in a southern state of the US. Three individuals were selected based on snowball sampling (Weiss 1995). Snowball sampling allowed us to recruit other participants for face to face interviews (Flick 2014). The study has three face to face interviews (one PhD student and two retired individuals). 


\section{Syrian Refugees and Americans}

Their ages ranged from 31 to 67 years. All face to face participants resided in a southern state in the US, with at least a master's degree.

For the content analysis portion of this study, we explored perception of Syrian refugees who are already resettled the US. Eleven family interviews [18 individuals] with Syrian refugees comprise the sample for the content analysis. For the content analysis, we used interviews conducted by Brandon Stanton, a photographer and journalists who shared stories and photos of Syrian refugee families Internet blog Humans of New York (Jacobs 2015). Stanton shared 11 Syrian refugee families' immigration stories and the way in which they lived as a refugee in the neighboring countries of Syria (Jacobs 2015).

Table 1 shows descriptive information of American participants of our respondents were white, had more than college degrees. Two were a retired husband and wife, while the other one was in his early 30s. John and Melanie have been married for 33 years and have lived in a southern small town for the entirety of their marriage. The sample is highly educated and politically identify themselves as 'liberals'.

Table 1

Descriptive information of American participants

\begin{tabular}{|c|c|c|c|c|c|}
\hline \multirow{2}{*}{$\begin{array}{l}\text { Name (All names are } \\
\text { Pseudonym) }\end{array}$} & \multirow{2}{*}{ Age } & \multirow[t]{2}{*}{ Sex } & Education Level & \multirow{2}{*}{\begin{tabular}{llr}
\multicolumn{2}{l}{ Self-position } & of \\
Political Scale & (Self \\
defined) & & \\
\end{tabular}} & \multirow{2}{*}{$\begin{array}{l}\text { Employment } \\
\text { Status }\end{array}$} \\
\hline & & & & & \\
\hline John & 67 & Male & $\begin{array}{l}\text { Master } \\
\text { Science }\end{array}$ & Liberal & Retired \\
\hline Melanie & 66 & Female & $\begin{array}{l}\text { Master } \\
\text { Education }\end{array}$ & Liberal & Retired \\
\hline David & 31 & Male & $\mathrm{PhD}$ degree & Liberal & Working \\
\hline
\end{tabular}

Table 2 shows descriptive information of Syrian refugees. All names appeared on Humans of New York and we used them as they appeared. The age of Syrian refugees was estimates were debated by several researchers. We have checked with several people to guess about age of Syrian refugees. 11 of Syrian refugees were in their early 30 years old, two refugees were in their late 30 years old, two children, and three refugees were between 60 and 70 years old. While eight refugees are women, 10 are male.

Table 2.

Descriptive Information of Syrian refugees 
Syrian Refugees and Americans

\begin{tabular}{|c|c|c|c|c|c|c|}
\hline & $\begin{array}{ll}\text { Names of } \\
\text { participants on } \\
\text { Humans of } \\
\text { New York }\end{array}$ & Age & Sex & $\begin{array}{l}\text { Education } \\
\text { Level }\end{array}$ & $\begin{array}{l}\text { Location of } \\
\text { Refugee }\end{array}$ & $\begin{array}{l}\text { Employment } \\
\text { Status }\end{array}$ \\
\hline \multirow[t]{2}{*}{$\begin{array}{l}\text { First } \\
\text { Interview }\end{array}$} & Ahmet & Early $30 \mathrm{~s}$ & Male & $\begin{array}{l}\text { University } \\
\text { student }\end{array}$ & Jordan & $\begin{array}{l}\text { Teacher } \\
\text { Literature and } \\
\text { French } \\
\text { Philosophy }\end{array}$ \\
\hline & Fatima & Early 30 s & Female & --- & Jordan & --- \\
\hline Second & Aise & 72 & Female & --- & Jordan & --- \\
\hline Interview & Mehmet & Early 30 s & Male & --- & Jordan & --- \\
\hline $\begin{array}{l}\text { Third } \\
\text { Interview }\end{array}$ & Necila & Late $30 \mathrm{~s}$ & Female & --- & Turkey & --- \\
\hline \multirow[t]{3}{*}{$\begin{array}{l}\text { Fourth } \\
\text { Interview }\end{array}$} & Kerim & 7 & Male & $\begin{array}{l}\text { Primary } \\
\text { School }\end{array}$ & Turkey & --- \\
\hline & Selim & 10 & Male & $\begin{array}{l}\text { Primary } \\
\text { School }\end{array}$ & Turkey & --- \\
\hline & $\begin{array}{l}\text { Nedim } \\
\text { Saliha }\end{array}$ & $\begin{array}{l}\text { Late } 30 \mathrm{~s} \\
\text { Late } 30 \mathrm{~s}\end{array}$ & $\begin{array}{l}\text { Male } \\
\text { Female }\end{array}$ & --- & $\begin{array}{l}\text { Turkey } \\
\text { Turkey }\end{array}$ & $\begin{array}{l}--- \\
---\end{array}$ \\
\hline $\begin{array}{l}\text { Fifth } \\
\text { Interview }\end{array}$ & Senem & Early $30 \mathrm{~s}$ & Female & $\begin{array}{l}\text { Master } \\
\text { Degree }\end{array}$ & Jordan & $\begin{array}{l}\text { Worked as a } \\
\text { Prof at the } \\
\text { University of } \\
\text { Damascus }\end{array}$ \\
\hline \multirow[t]{2}{*}{$\begin{array}{l}\text { Sixth } \\
\text { Interview }\end{array}$} & Ali & Early $30 \mathrm{~s}$ & Male & $\begin{array}{l}\text { College } \\
\text { Degree }\end{array}$ & Turkey & --- \\
\hline & Zeynep & Early 30 s & Female & $\begin{array}{l}\text { Medical } \\
\text { School }\end{array}$ & Turkey & Medical Doctor \\
\hline $\begin{array}{l}\text { Seventh } \\
\text { Interview }\end{array}$ & Hamo & Late $60 \mathrm{~s}$ & Male & PhD Degree & Turkey & Professor \\
\hline $\begin{array}{l}\text { Eighth } \\
\text { Interview }\end{array}$ & Aynur & Early $30 \mathrm{~s}$ & Female & --- & Turkey & --- \\
\hline $\begin{array}{l}\text { Ninth } \\
\text { Interview }\end{array}$ & Nawar & Early 30 s & Male & --- & Jordan & $\begin{array}{l}\text { Had his own } \\
\text { business } \\
\text { Driver }\end{array}$ \\
\hline $10^{\text {th }}$ & Sedat & Early 30s & Male & --- & Jordan & --- \\
\hline Interview & Omer & Late $60 \mathrm{~s}$ & Male & --- & Jordan & --- \\
\hline $\begin{array}{l}11^{\text {th }} \\
\text { Interview }\end{array}$ & Aya & 20 & Female & & Turkey & --- \\
\hline
\end{tabular}

\section{Face to Face Interviews}

We conducted face to face interviews with three individuals in a southern state of the US. Participation in a local running club allowed for initial entry. A request for interviews was sent to the organizer of the club, who then forwarded the information to members. This netted one participant, who further referred us to other willing participants. 


\section{Syrian Refugees and Americans}

Interviews with participants lasted between 45 to 50 minutes. After consent was secured, interviews were recorded using audio devices. We also took field notes during interviews and revisited observational notes after each interview. Interviews were conducted in settings requested by the interviewees. In one case, we met the subject at his residence. During the interview, his wife spontaneously entered into the ongoing conversation and we allowed her participation. After conducting this first interview, we requested his assistance in securing additional participants.

Voice records of each interview were transcribed prior to analysis. We used line-by-line coding and a systematic thematic approach for each interview (Flick 2014). Themes were extracted and organized from each interview. Next, we focused on each main theme to match content analysis coding in attempts to find similarities and differences between Americans and Syrian refugees.

\section{Content Analysis of Syrian Refugees - Humans of New York}

For content analyses, we used a thematic coding process (Flick 2014). While coding transcriptions of Syrian refugees, we simultaneously examined the coding of the face to face interviews. We highlighted similarities and differences between Syrian refugees' and Americans. Face-to-face interviews. Two main concepts emerged: 1) Immigration, 2) Attitudes and fear. Based on these two main concepts, we further analyzed content for Syrian refugees and American.

\section{Findings}

Analyses of American participants of Syrian refugees show that the meaning of migration varies. Three main themes emerged from the analysis of both face to face interviews and content analysis sections: Meaning of Immigration for Americans participants and Syrian refugees, Contrasting compassion and fear of Syrian refugees, and Attitudes of Syrians towards Americans.

Theme one: Meaning of Immigration for Americans Participants and Syrian Refugees

a) Meaning of migration for Americans

Analyses indicate that there are differences in meaning of immigration for American participants and Syrian refugees. For American participants, immigration is mostly associated with 'un-documented immigrants' and therefore seen in a negative light. John, who is 67 years old, previously employed by the US military and currently retired, expressed his concerns about immigration:

This is what I think about immigration. Anyone who wants to come to the US, anyone who wants to come here legally through proper process, just like what I have to do if I want to go to France or anywhere else in Turkey. I could not slip into your country. If I did, I would probably be caught and be deported or whatever. But I would face consequences. If I went to Turkey, undocumented, illegally... There is some, some, some people would say that undocumented immigrants are taking jobs from Americans. But the fact of the matter is many Americans would not do the jobs that they are working. (April 10, 2016). 


\section{Syrian Refugees and Americans}

For John, immigrants who come to the US in a legal way are acceptable. He immediately made a connection with 'undocumented' immigrants. Although Syrian refugees are documented and have gotten through formal state processes, for John, immigration remains associated with undocumented entrance into the US. While John ascribed a negative meaning to immigration associated with undocumented refugees, he also touched upon an economic aspect of immigration, in which he felt immigrants were a threat to jobs for Americans.

David, 31 years old, who holds a master degree and has engaged with several individuals from Middle Eastern countries, indicated his view of immigrants as follows;

I think they are an asset. These are new ideas, this is new energy, and these are new skills for employment... Immigration, in general, is a good thing for the economy. You get more out of it. They bring more actually than they take away. So, overall it is a benefit to our country to have immigrants' in. (April 15, 2016)

The United States has one of the largest undocumented immigrant populations in the world, expressed as a concern for both John and David. David has a similar perspective as John in terms of immigration, indicating that if people come to the United States legally and documented then it is acceptable, but an influx of illegal immigrants is grounds for concern. Both David and John mention potentially negative economic consequences of immigration; however, both agree that immigrants can also contribute to the American economy. According to John, immigrants are needed due to the type of work in which they are employed. According to David, they come up with new ideas and energy that, which makes them acceptable for American society.

The resettlement of Syrian refugees to the US was an important political debate during the American presidential election in 2016. Our participants were aware of resettlement of Syrian refugees to the US; however, they lacked knowledge on the specific number of incoming Syrian refugees. When asked about the resettlement of Syrian refugees the US, John explained;

I see this as a more European problem than an American problem. If Mexico all of sudden blew up, and there were millions of Mexican, South American, and Central Americans fleeing to the US, we would not send them to Europe. We would not ask to Germany to take 100,000 Mexicans. We would handle that situation. So, I don't really see why Europe is not handling the situation or the European Union is not handling the situation better than they are. That makes sense? (April 10, 2016).

For John, migration is generally associated with Mexican or South American immigrants. For John, documented immigrants from South American countries do not appear to pose a problem. Syrian refugees, however, represents more of a European problem than a US problem due to geographical distances between the US and Syria.

b) Meaning of migration for Syrian refugees

Turkey and Jordan are the two countries that mostly handled the Syrian humanitarian crisis, accepting about four million refugees (Aydin \& Kaya 2017). However, both are developing countries with limited resources to meet the needs of Syrian refugees (Akgul et al. 2015; Kirisci 2014). Although both countries provide more safety compared to conditions of the Syrian Civil 


\section{Syrian Refugees and Americans}

War, refugees continue to experience harsh conditions, including accommodation problems, mental and physical health problems, transportation, language barriers, and employment issues (Akgul et al. 2015; Aydin \& Kaya 2017). Given this reality, the US is seen as a more advantageous destination compared to other less developed countries such as Turkey and Jordan. Despite still maintaining status as a refugee, the meaning attached refugee status in the US is different than being a refugee in Jordan and Turkey. Although they will still be refugees in the US, the meaning of immigration in the US comes with hope, future plans, and the potential to start a new and meaningful life.

Senem, a widowed mother approximately 30 years old and a former professor at University of Damascus, moved to Jordan when the civil war began in Syria. She shared her experience of being a refugee in Jordan;

Because I'm a refugee, my life is on pause. My studies have stopped. I'm not working. I don't have a career. Because I'm Syrian, I'm not allowed to participate in society. It's been years of doing nothing. I used to be a cheerful person. I was always invited to parties. Now I like to be alone. I've become more nervous and aggressive. I yell over silly things. I just want to start my life again. (2015).

For Senem, being a refugee in Jordan and a widowed woman came with negative psychological consequences. This is supported by peer-reviewed articles, which focused on the mental health of refugees in camps (Dejong et al. 2017; McNelly, 2016).

Her rationale for moving from Syria to Jordan and then to the US can be interpreted using push and pull models of immigration (Massey et al. 1993). The Syrian Civil War forced her to move to Jordan but her refugee status in Jordan [without a work permit] limited her ability to fully participate in society. This lack of participation partially precipitated her application to the US for refugee status. Pull factors of the US, including perceived job opportunities, housing, and educational opportunities were the main drivers of her decision to move to the US.

Zeynep is a married medical doctor and had been living in Turkey for three years prior to moving to the US. She and her husband both have college degrees and had previously lived in Syria. Zeynep was forced to work for ISIS, refused to work for ISIS and therefore moved to Turkey. As a medical doctor, she perceived she would be welcome in Turkey. However, refugees are not allowed to practice medicine in Turkey.

As a result, Zeynep cites similar push and pull factors leading to her decision to move to the US;

We've been waiting for two years now. We've been through all our interviews. Last week this letter came and said that we've been 'deferred.' I'm not even sure what that means. We were very truthful about everything. We have nothing left in Syria. I want to continue working as a doctor in America. Here my hands are tied. Refugees are not allowed to work. I don't have papers. I can't communicate with anyone. I worked my entire life to become a doctor. I did nothing but study for six years. I didn't even have a hobby. Now I'm doing nothing. I'm losing hope. I've started to wonder if it would have been better for us to go the illegal way across the sea. (2015) 


\section{Syrian Refugees and Americans}

Zeynap and her family were eventually granted admission to the US. Push and pull factors of immigration played roles in Zeynep's situation as well. She, as a medical doctor and with a highly educated husband, felt the pull of opportunity from the United States to continue medical practice.

Hamo, an approximately 60 years old a scientist with a $\mathrm{PhD}$ degree, cited similar reasons, in addition to a loss of family members and accumulated wealth in Syria. Hamo stated;

Everything that wasn't destroyed in our house was stolen over the next two days. We left with nothing. I can't even pay the rent of this apartment. I've been in Turkey for two years now. I'm dead here. I have no life, no respect, and my children aren't going to school. I have a PhD but I'm not allowed to work without a residence permit. There is a university here that is teaching with a book I wrote, but still won't give me a job. In order to survive, I'm forced to create designs and give them away to Turkish citizens, who take all the credit and pay me barely enough money to cover the costs of my materials. This year I created blueprints for a giant construction project of 270 big houses. I was paid maybe one percent of what a Turkish citizen would have earned. There is no respect for my work here. Only money is respected.

Hamo was ultimately admitted to the United States in early 2016. Being a refugee in Turkey mean being dead for Hamo. Despite a desire to contribute to society through his educational background and knowledge, his refugee status inhibited his ability to work and he was forced into an informal labor market in which he felt exploited. As such, similar push and pull factors drove his desires to migrate to the US.

\section{Theme two: Contrasting compassion and fear of Syrian refugees}

A survey from the Pew Research Center found that more than half of registered American voters did not approve of US accepting refugees from Syria, while 41 percent did. (Krogstad \& Radford 2017). To examine the attitudes of American towards Syrian refugees, as well as expectations and attitudes of Syrian refugees towards Americans, we asked American participants about their feelings of Syrian refugees and how they would feel if they became neighbors. John stated that,

I have mixed feelings. I have mixed feelings. Now, he tells us that they will be weeded out. The FBI director says there is no way that they can be weeded out. So somebody is lying, either the FBI director or the president. When we, if somebody, and I know you cannot weed everything hundred percent. But the FBI director says that there is no background check that they can do on refugees. Because there is no infrastructure in Syria that you can call. So, it does worry me. I think, I think the ISIS is smart enough to embed terrorists in the refugees. Another thing that worries me when I watch the TV, this is a snapshot, when I see refugees in Europe, I see young men. I don't see old women and children; I see young men. One thing is that old women and children cannot make such a horrible trip. So, you have to be a strong young man. I am not sure that young men should not be in their country fighting for their rights. So that worries me a little bit. If you look at it, from a humanitarian, yes. Your heart goes out, when you see people who are fleeing out from their country with nothing with children, obviously you are compassionate. But you have to balance there, in my opinion. You know, how many Americans do I want to die. If I was the president, what I am willing to risk? Am I willing to risk 25 Americans, if 


\section{Syrian Refugees and Americans}

only one terrorist get through and gets one bomb? Am I willing to risk an airplane going down? Is that worth it? I don't know. I am glad that it is not my decision... (April 10, 2016)

He further states:

And I think that is most Americans feel. I think most Americans are compassionate, we welcomed most anybody to this country. I think, anyone is welcome here. Even though most conservative of us would welcome anyone who wants to come here and contribute, follow the laws, blended to the society. But you know, I am balanced over ISIS.

John has military experience and therefore uses his military knowledge to frame his responses. He worries that IS affiliated terrorists will come to the US amongst Syrian refugees, increasing the likelihood of terrorist attacks. For John, these concerns make him very conflicted. Although he wants to help Syrian refugees, he perceives significant risk to both himself and the American public. This perceived risk is further amplified based on perceptions that Syrian refugees are primarily young males, which is also apparent in previous literature (Rettberg \& Gajjala 2015).

David expresses similar contrasting humanitarian concerns and acknowledgement of risk. From a humanitarian perspective, he sides with John and believes that Syrian refugees need help due to bleak situations in their country of origin. Despite not personally acknowledging fear, David mentions the fear-driven perceptions of other Americans towards Syrian refugee resettlement in the US:

I heard from people and read from social media channels, I have an image of a kid drawn to the shore... And then, of course just seeing, I heard about refugee camps and how countries are hesitant to let them in. There is fear of ISIS, extremism and stuff like that. (April 15, 2016).

People have concerns about Syrian refugees right now that, a: they will take away American jobs; b: with the Syrians I think, it is an issue with terrorism. I think both of those are more rooted in fear, and typically people who are scared are the people who feel most threatened to lose their employment which is lot of more uneducated people. Less educated people feel more threatened that their position is going to be taken. (April 15, 2016).

David typically uses social media to get news about the US and international events. For David, the widely circulated image of a drowned Syrian refugee infant is very symbolic of a need to offer compassion and empathy. Refugee camps and Syrian treks to European countries were heavily covered in American TV channels and newspapers. David believes that there is a fear of IS attached to Syrian refugees. David believes that Syrian refugees should be helped; however he also cites concerns for ISIS and a threat of terrorism.

Melanie is in her 60s and has a master degree in education. She has maintained interactions with international students and faculty members and has even hosted visits from international acquaintances. These experiences surely shape her perspective on American management of the Syrian refugee crisis. She states: 


\section{Syrian Refugees and Americans}

I mean, if I had to decide if there were a large group of people who are saying "please help us", there is no way I could say no. But, how do you know that you are safe when you say yes? How do you know? I don't know. I don't know the answer. I would not want to turn people away, when they need my help. But at the same time, what if my saying come on in hurts somebody here? I don't know. (April 10, 2016)

I would feel fine about them. I mean, they are here because they want to be safe, they want to have a better life, they want to work, and participate, and to our culture. And this is great. (April 10, 2016)

Melanie exhibits a humanitarian perspective, similar to that of John and David. However, she also expresses concerns of threat and fear of 'unknown' or 'what if'scenarios regarding perceived dangers associated with Syrian refugees.

Overall, participants state positive perceptions of Syrian refugees including their ability to contribute socially and economically, while simultaneously expressing fear and concerns regarding perceptions of threat and terrorism, a link often readily available in media portrayals of Middle Eastern men (Rettberg \& Gajjala 2015; Wall et al. 2016). In the event of admission through formal and legal processes, Americans are generally welcoming of Syrian refugees. However each American explicitly states some unease with the potential dangers associated with their entry.

\section{Theme three: Attitudes of Syrian towards America}

Syrian refugees accepted into the US generally express great hope about their future. While some of them have social networks including relatives, family members, or others from Syria already residing in the US who assist with acculturation into a new society, others state distress due to a lack of social networks and a lack of knowledge of their new city. Aise, an elderly woman admitted to the US at the same time as her son, states:

Tomorrow he's (her son) leaving for a place called Memphis, Tennessee. I don't know what I will do without him. I hope they will let me come to Memphis too. Can you tell us anything about Memphis? Are there nice people there? I heard that it is a city of music. I love music.

Kerim and Selim, two Syrian refugee children, aged 7 and 10, discuss how their perceptions of the US are shaped by socialization processes stemming from media and their parents:

We are going to a place called Clearwater, Florida. I don't know a lot about it. I saw Florida on the television and it looks like it's close to the sea and has a lot of plants. My dad says the people are friendly and there are a lot of friendly kids there. I really hope that we can have a small farm and a horse when we get there because my grandmother really loves animals. I'd like it to be a square farm with lots of flowers and rabbits. I also hope there is a good tree in Florida because I'd like to build a tree house where we can have some adventures.

Once they arrive in the US, Syrian refugees generally hold hopeful feelings full of opportunities, opportunities for their future, happiness, ability to participate in society, and living out their own "American Dream" through hard work. From the interviews, it is clear that the United 


\section{Syrian Refugees and Americans}

States retains a powerful and symbolic image for immigrants as a land of opportunity. Despite maintaining refugee status, the positive symbolism associated with the US brings happiness and hope. As an example, Senem, a widowed mother in her early 30s, optimistically deliberates on her daughter's future in the US, also discussing her daughter's own excitement:

Doesn't she look like an American? The lady who did our interview said that she looks like an American. She's very excited. She's young, so I know she'll be able to learn English very easily. She's a very smart girl. She's already decided exactly what her room will look like in North Carolina. She won't stop talking about it. She says that she's going to do a lot of swimming and learn how to use the computer. Someone at her school told her that kids in America can do whatever they want and never get yelled at. So whenever I try to punish her, she tells me: 'That won’t be allowed in America. (2015).

\section{Discussion and Conclusion}

The Syrian refugee crisis received extensive coverage, especially during the 2016 US presidential election in which both candidates proposed their perspectives on the resettlement of Syrian refugees in the US. The Syrian refugee crisis is a humanitarian crisis, negatively impacting the Syrian region as well as countries of resettlement. Several studies have been conducted in the US pertaining to the admission of Syrian refugees, but these have utilized strictly quantitative approaches (Dawson-Hahn et al. 2016; Galston 2016; Hooper et al. 2017). And although quantitative methods are able to provide a vast wealth of information about attitudes from the American public, response depth is typically limited. Our analyses extend the previous literature by focusing on attitudes and perceptions of Americans towards Syrian refugees, as well as perceptions of Syrian refugees towards the US using qualitative methods. From face to face interviews with American citizens, as well as content analyses of interviews with Syrian refugees, we identified and presented several prominent themes: Meaning of Immigration for Americans participants and Syrian refugees, Contrasting compassion and fear of Syrian refugees, and Attitudes of Syrian towards Americans.

We found Americans held oppositional and conflicting attitudes towards Syrian refugees. On the one hand, Americans expressed empathy and a willingness to aide Syrian refugees in the United States, driven by humanitarian concerns. In contrast, these statements of compassion and empathy simultaneously indicated a sense of hesitancy. This hesitancy resulted from perceptions of fear that an influx of refugees would threaten jobs that Americans might otherwise hold and a fear of terrorism. For Syrian refugees, the meaning of migration and refugee status varied according to the country of resettlement. Content analyses showed that the meaning of resettlement varied based on the country of resettlement. Forced migration to neighboring countries of Syria such as Turkey and Jordan was associated with feelings of social exclusion, as an inability to secure admission into the formal labor market precluded their ability to provide for their own basic needs. In contrast, voluntary admission to the US represented hope, opportunity, and being able to contribute. Despite this optimism, Syrians often expressed a lack of knowledge of social and cultural expectations of the US. 


\section{Syrian Refugees and Americans}

Analyses indicate that the meaning of immigration varies for American participants and for Syrian refugees. For American participants, migration was generally associated with 'undocumented' migrants; therefore, respondents expressed a negative stigma associated with Syrian refugees, in which American economic and civil security are threatened through loss of American jobs and terrorism. While Americans felt Syrian refugee admission through legal processes was acceptable, it also appeared that American participants were not aware of the difference between undocumented migrants and refugees.

The lack of knowledge of this distinction between refugee status and undocumented status led Americans to have complex attitudes towards Syrian refugees. Americans mistakenly attribute Syrians' status as refugees for undocumented immigrants. When viewed as illegal immigrants, the narrative from Americans tends to follow those apparent in previous studies- that large numbers of illegal immigrants threaten American jobs and place an unnecessary burden on American taxpayers who are forced to cover the added expenses to social institutions (Hanson \& Spilimbergo 1996; Hanson et al. 2002; Michou, et al., 2016). Regardless of the mistaken attribution of refugee status to illegal immigrants, American participants still maintained attitudes of tolerance and empathy towards Syrians largely as a result of media coverage of the Syrian Civil War and conditions of Syrians in refugee camps.

The portrayal of Middle Eastern men in social mainstream media is often negative, highly politicized and threatening to western values (Rettberg \& Gajjala, 2015). Syrian male refugees have been portrayed as rapists, terrorists, cowards, and not 'true' refugees (Rettberg \& Gajjala, 2015). Findings from our study coincided with this; specifically, Americans indicated fears associated with terrorism from Syrian refugees. Americans felt as though admission of Syrian refugees into the US as political refugees was problematic, despite doing so as legal and documented refugees. This is indicative of a dynamic process within American narratives on immigrants and individuals from the Middle East. Despite statements indicating a willingness to admit anyone willing to enter the country through legal and formal processes, this willingness is immediately challenged when Middle Eastern ethno-religious descent is included. Regardless of the formality and legality of the Syrian refugee admission process, they are still confronted with suspicions of threat similar to those portrayed in the media.

This study is not without limitations. A primary limitation is the small sample size of Americans utilized. In addition to the small sample size, the Americans which were interviewed are not representative of Americans in general on several key indicators, including educational attainment or self-reported political positioning. As such, caution is warranted in any generalization of the findings to the greater USA. Regardless, we feel that our findings are of utility as an exploratory study into relations between Americans and Syrians. The data on Syrian refugees for content analysis have limitations in that the interviews are not complete, instead only presenting portions of the full exchange. Regardless, they represent vital contributions to our exploratory study and provide key insight into Syrian perceptions of America which can be analyzed and further explored with input from larger samples. 
Syrian Refugees and Americans

Future studies might include interviews with Syrian refugees about their experiences in the host country after they arrive. Topics of interest include health conditions, adaptation, the way they are treated in their new communities, difficulties of accommodation, social inclusion, and navigation of new social institutions with often limited resources.

\section{Disclosure statement}

No potential conflict of interest was reported by the authors.

\section{Funding}

This research received no specific grant from any funding agency in the public, commercial, or non-profit sectors.

\section{References}

Abbas, T., \& Yigit, I. H. (2015). Scenes from Gezi Park: Localisation, nationalism and globalization in Turkey. City, 19(1), 61-76.

Abbas, T., \& Yigit, I. H. (2016). Perspectives on Ethno-National Conflict among Kurdish Families with Members in the PKK. Terrorism and Political Violence, 28(2), 297-315.

Adnan, G., \& I. Coles. (2017, December 09). Iraqi Forces Drive Islamic State from its Remaining Territory. The Wall Street Journal. Retrieved from (https://www.wsj.com/articles/iraqiforces-drive-islamic-state-from-its-remaining-territory-1512834670)

Aguirre, A. J., \& Turner, J. H. (2016). American ethnicity: the dynamics and consequences of discrimination. New York, NY: Mcgraw-Hill.

Akgul, A., A. Kapti, \& O. O. Demir. (2015). Migration and Public Policies: An Analysis of Syrian Crisis. The Global: A Journal of Policy and Strategy, 1(2), 1-22.

Aydin, H., \& Y. Kaya. (2017). The Educational needs of and Barriers faced by Syrian Refugee Students in Turkey: A Qualitative Case Study. International Education, 28(5), 456-473.

Cainkar, L. A. (2009). Homeland Insecurity: The Arab American and Muslim American Experience after 9/11. New York, NY: Russell Sage Foundation.

Carasik, L. (2015). OPINION: US leaders cave to popular fear on Syrian refugees. Retrieved from http://america.aljazeera.com/opinions/2015/11/us-leaders-cave-to-popular-fear-on-syrianrefugees.html

Christophersen, M., J. Liu, C. M. Thorleifsson, \& A. A. Tiltnes. (2013). Lebanese attitudes towards Syrian refugees and the Syrian crisis: Results from a national opinion poll implemented 15-21 May, 2013. Fafo Paper 2013. Retrieved from http://www.fafo.no/images/pub/2013/10179.pdf.

Çitamak, Y., \& Yigit, I., H. (2012). From Student Desk to Teacher's Table. International Journal of New Trends in Arts, Sports \& Science Education, 1(2), 8-14. 
Syrian Refugees and Americans

Dawson-Hahn, E., Pak-Gorstein, S., Hoopes, A. J., \& Matheson, J. (2016, December 12). The Nutritional Health of Young Refugee Children Resettling in Washington State. Retrieved from https://www.migrationpolicy.org/research/nutritional-health-young-refugeechildren-resettling-washington-state

Dejong, J., Sbeity, F., Schlecht, J., Harfouche, M., Yamout, R., Fouad, F. M., Robinson, C. (2017). Young lives disrupted: gender and well-being among adolescent Syrian refugees in Lebanon. Conflict and Health, 11(1), 1-23.

DeSilver, D. (2015). U.S. public seldom has welcomed refugees into country. Retrieved from http://www.pewresearch.org/fact-tank/2015/11/19/u-s-public-seldom-has-welcomedrefugees-into-country/

Ersoy, E. (2015). Assessment of Adolescent Perceptions on Parental Attitudes on Different Variables. Journal of Education and Training Studies, 3(5), 165-176.

Galston, W. A. (2016). What Americans really think about the Syrian refugee crisis? Retrieved from https:/www.brookings.edu/blog/markaz/2015/09/30/what-americans-really-thinkabout-the-syrian-refugee-crisis/

Faltis, C. (2014). Toward a Race Radical Vision of Bilingual Education for Kurdish Users in Turkey: A Commentary. Journal of Ethnic and Cultural Studies, 1(1), 1-5.

Flick, U. (2014). An Introduction to Qualitative Research, $5^{\text {th }}$ edition. Thousand Oaks; CA: Sage.

Gilsinan, K. (2015). The Confused Person's Guide to the Syrian Civil War. Retrieved from http://www.theatlantic.com/international/archive/2015/10/syrian-civil-war-guideisis/410746/

Gardiner Harris, David E. Sanger, \& David M. Herszenhorn. (2015). Obama Increases Number of Syrian Refugees for U.S. Resettlement to 10,000. Retrieved from http://www.nytimes.com/2015/09/11/world/middleeast/obama-directs-administration-toaccept-10000-syrian-refugees.html?_r=0

Hanson, G., \& Spilimbergo, A. (1996). Illegal Immigration, Border Enforcement, and Relative Wages: Evidence from Apprehensions at the U.S.-Mexico Border. American Economic Review, 89(5), 1337-1357.

Hanson, G. H., Scheve, K. F., Slaughter, M. J., \& Spilimbergo, A. (2002). Immigration and the U.S. Economy: Labor-Market Impacts, Illegal Entry, and Policy Choices. SSRN Electronic Journal. doi:10.2139/ssrn.296108

Holdsworth, C., N. Finney, A. Marshall, \& Norman, P. (2013). Population and Society. London: Sage.

Hooper, K., Zong, J., Capps, R., \& Fix, M. (2017). Young Children of Refugees in the United States: Integration Successes and Challenges. Retrieved from https://www.migrationpolicy.org/research/young-children-refugees-united-statesintegration-successes-and-challenges

Icduygu, A. (2015). Syrian Refugees in Turkey: The Long Road Ahead. Retrieved from https://www.migrationpolicy.org/research/syrian-refugees-turkey-long-road-ahead 
Syrian Refugees and Americans

Jacobs, S. (2015). 20 stunning portraits from the 'Humans of New York' photographer's interviews with Syrian refugees. Retrieved from http://www.businessinsider.com/syrian-refugeestories-told-by-humans-of-new-york-2015-12/\#istanbul-turkey-1

Jones, S. G. (2015). The terrorism threat to the United States and Implications for Refugees. RAND Office of External Affairs. Retrieved from https://www.rand.org/content/dam/rand/pubs/testimonies/CT400/CT433/RAND_CT433. pdf

Kaya, Y. (2015). The Opinions of Primary School, Turkish Language and Social Science Teachers regarding Education in the Mother Tongue (Kurdish). Journal of Ethnic and Cultural Studies, 2(2), 33-46.

Kirişci, K. (2016). Syrian Refugees and Turkey's Challenges: Going beyond Hospitality. Retrieved from https://www.brookings.edu/research/syrian-refugees-and-turkeys-challengesgoingbeyond-hospitality/

Krippendorff, K. (2003). Content Analysis: An Introduction to its Methodology. Thousand Oaks, CA: Sage.

Kritz, M. M., Keely, C. B., \& Tomasi, S. M. (2004). Global trends in migration: theory and research on international population movements. Ann Arbor, MI: UMI Books on Demand.

Krogstad, J. M., \& Radford, J. (2017). Key facts about refugees to the U.S. Retrieved from http://www.pewresearch.org/fact-tank/2017/01/30/key-facts-about-refugees-to-the-u-s/

Martin, P. L., \& Midgley, E. (2006). Immigration: shaping and reshaping America. Washington, DC: Population Reference Bureau.

Massey, D. S., Arango, J., Hugo, G., Kouaouci, A., Pellegrino, A., \& Taylor, J., E. (1993). Theories of International Migration: A Review and Appraisal. Population and Development Review, 19(3), 431-466.

Mcneely, C. A., \& Morland, L. (2016). The Health of the Newest Americans: How US Public Health Systems Can Support Syrian Refugees. American Journal of Public Health, 106(1), 13-15.

Michou, A., Mouratidis, A., Ersoy, E., \& Uğur, H. (2016). Social achievement goals, needs satisfaction, and coping among adolescents. Personality and Individual Differences, 99, 260-265.

Newport, F. (2015). Historical Review: Americans' Views on Refugees Coming to U.S. Retrieved, from http:/www.gallup.com/opinion/polling-matters/186716/historical-reviewamericans-views-refugees-coming.aspx

Portes, A., \& Borocz, J. (1989). Contemporary Immigration: Theoretical Perspectives on Its Determinants and Modes of Incorporation. International Migration Review, 23(3), 606.

Rettberg, J. W., \& Gajjala, R. (2015). Terrorists or cowards: negative portrayals of male Syrian refugees in social media. Feminist Media Studies, 16(1), 178-181.

Scarboro, A. \& Yigit, I., H. (2014). Social Distance in Today's Istanbul: Politics and Exceptionalism. Journal of Research in Humanities and Social Science, 2(6), 1-13.

Sharara, S. L., \& Kanj, S., S. (2014). War and Infectious Diseases: Challenges of the Syrian Civil War. PLoS Pathogens, 13(10), 38-44. 
Syrian Refugees and Americans

Sirin, S. R., \& Rogers-Sirin, L. (2017). The Educational and Mental Health Needs of Syrian Refugee Children. Retrieved from https://www.migrationpolicy.org/research/educationaland-mental-health-needs-syrian-refugee-children

Worldwide Refugee Admissions Processing System (WRAPS). (2017). Refugee Admissions Report October 31, 2017. Retrieved from http://www.wrapsnet.org/s/RefugeeAdmissions-Report-2017_10_31-1.xls

Wall, M., Campbell, M. O., \& Janbek, D. (2016). Syrian refugees and information precarity. New Media \& Society, 19(2), 240-254.

Weiss, R. S. (1995). Learning from strangers: the art and method of qualitative interview studies. New York: Free Press.

Yigit, Ismail H. (2015). Survival Tactics of Waste Paper Pickers in Istanbul. Journal of Ethnic and Cultural Studies, 2(1), 1-14.

Zong, J. (2016, January 25). Profile of Syrian Immigrants in the United States. Retrieved from https://www.migrationpolicy.org/research/profile-syrian-immigrants-united-states.

Manuscript received December 04, 2017

Final revision received December 19, 2017

Accepted December 26, 2017

Ismail Hakki Yigit is a $\mathrm{PhD}$ candidate in the sociology department at Mississippi State University. His research broadly examines health outcomes of social inequalities, stratification, and ethnic, religious, and racial minorities. His work can be found in academic journals including Journal of Ethnic and Cultural Studies, Terrorism and Political Violence, and City.

Andrew Tatch is a $\mathrm{PhD}$ candidate in the sociology department at Mississippi State University. He is currently employed at the Mississippi State University Social Science Research Center. His research broadly examines physical and mental health disparities, substance use and abuse, and impaired driving. 